\title{
Increasing burden of $E$. coli bacteraemia and changing epidemiology
}

\author{
J Wilson ${ }^{1 *}$, R Coello ${ }^{1}$, A Jepson², E Brannigan ${ }^{1}$, M Richards' ${ }^{1}$ S Hassall ${ }^{1}$, A Holmes ${ }^{1}$ \\ From International Conference on Prevention \& Infection Control (ICPIC 2011) \\ Geneva, Switzerland. 29 June - 2 July 2011
}

\section{Introduction / objectives}

According to National surveillance in England S. aureus as a cause of bacteraemia has recently declined but that due to E. coli has increased by 33\%. Mandatory reporting of E.coli is being introduced in 2011. At Imperial College Healthcare we investigated $E$. coli bacteraemia occurring between July 2008 and June 2010

\section{Methods}

Microbiological records of patients with E. coli bacteraemia were linked with patient data to determine their characteristics, whether CA or HA, and if the E. coli produced ESBL. Blood cultures taken within 2 days of admission were defined as $C A, 2$ days or more after admission as HA and a new episode if greater than 2 weeks between positive blood cultures. E. coli ESBL was defined by resistance to cefpodoxime, or by resistance to ceftazidime or cefotaxime whilst remaining susceptible to cefoxitin. Where possible, the potential source of the bacteraemia was determined from the antibiotic profile of E.coli isolated concurrently from other specimens.

\section{Results}

668 E. coli bacteraemia were detected ( $12 \%$ of all positive blood cultures), of which $67 \%$ were CA; $53 \%$ were female. For CA cases, the proportion of females (55\%) was higher than males, whilst for HA cases, males accounted for more cases than females (47\%). E, coli bacteraemia was more common in patients 65 years and over, accounting for $44 \%$ of CA and $49 \%$ of HA cases. Of the 668, $110(16 \%)$ produced ESBL, of which 61 (55\%) were CA. Overall, $14 \%$ of CA and $22 \%$ of HA cases were ESBLs. The source was identified for $35 \%$ of cases; in $30 \%$ of these the urinary tract was responsible.

${ }^{1}$ Infection prevention \& control, Imperial College Healthcare NHS Trust, London, UK

Full list of author information is available at the end of the article

\section{Conclusion}

E.coli, is an important cause of CA and HA bacteraemia with a significant proportion ESBL-strains. Mandatory reporting may facilitate understanding of the epidemiology and target prevention strategies.

\section{Disclosure of interest}

None declared.

\section{Author details}

${ }^{1}$ Infection prevention \& control, Imperial College Healthcare NHS Trust, London, UK. ${ }^{2}$ Microbiology, Imperial College Healthcare NHS Trust, London, UK.

Published: 29 June 2011

\section{doi:10.1186/1753-6561-5-S6-O3}

Cite this article as: Wilson et al:: Increasing burden of E. coli bacteraemia and changing epidemiology. BMC Proceedings 2011 5(Suppl 6): $\mathrm{O} 3$.
Submit your next manuscript to BioMed Central and take full advantage of:

- Convenient online submission

- Thorough peer review

- No space constraints or color figure charges

- Immediate publication on acceptance

- Inclusion in PubMed, CAS, Scopus and Google Scholar

- Research which is freely available for redistribution
() Bïomed Central
(C) 2011 Wilson et al; licensee BioMed Central Ltd. This is an open access article distributed under the terms of the Creative Commons Attribution License (http://creativecommons.org/licenses/by/2.0), which permits unrestricted use, distribution, and reproduction in any medium, provided the original work is properly cited. 